Asian J. Med. Biol. Res. 2020, 6 (4), 754-760; doi: 10.3329/ajmbr.v6i4.51243

\author{
Asian Journal of \\ Medical and Biological Research \\ ISSN 2411-4472 (Print) 2412-5571 (Online) \\ www.ebupress.com/journal/ajmbr
}

\title{
Article \\ Anti-oxidant, pediculicidal and pesticidal activities of leaves of Rhinacanthus nasutus (Linn) grown in Sri Lanka
}

\author{
Vajira. P Bulugahapitiya*, Fernando P.T.N and Jayasekara H. D. \\ Department of Chemistry, Faculty of Science, University of Ruhuna, Matara 81000, Sri Lanka \\ *Corresponding author: Vajira. P Bulugahapitiya, Department of Chemistry, Faculty of Science, University of \\ Ruhuna, Matara 81000, Sri Lanka. E-mail: vajira@chem.ruh.ac.lk
}

Received: 26 November 2020/Accepted: 14 December 2020/ Published: 31 December 2020

\begin{abstract}
Rhinacanthus nasutus is an ethnomedical plant used in the traditional system of medicine for treating skin diseases. As no adequate studies available on $R$. nasutus grown in Sri Lanka, this study aimed on exploring anti-oxidant, anti-parasitic and pesticidal activity of leaves of the plant. Antioxidant capacity of the crude extract of leaves was evaluated using DPPH free radical scavenging assay and FRAP assay using ascorbic acid and $\mathrm{FeSO}_{4} \cdot 7 \mathrm{H}_{2} \mathrm{O}$ as the standards respectively. Pediculicidal efficacy was carried out against head lice using $0.0010 \%(\mathrm{w} / \mathrm{v})$ methanolic, ethyl acetate and aqueous extracts of leaves by following modified filter paper diffusion bioassay. Pesticidal activity of leaves was evaluated using modified filter paper contact bioassay against mealybugs, $P$. marginatus, resides on papaw and guava trees. The $\mathrm{IC}_{50}$ value of DPPH assay was found to be $514.3 \mu \mathrm{gmL}^{-1}$ and FRAP value was found to be $594.33 \pm 2.93 \mu \mathrm{mol} \mathrm{Fe} / \mathrm{g}$ in anti-oxidant assay. The $\mathrm{LT}_{50}$ (median Lethal Time) values for $0.0010 \%(\mathrm{w} / \mathrm{v})$ concentration of methanolic, ethyl acetate and aqueous extracts were 263,347 and 676 min respectively in pediculicidal assay. $\mathrm{LC}_{50}(50 \%$ mortality) value was found to be $0.0011 \%(\mathrm{w} / \mathrm{v})$ after 240 minutes whereas $\mathrm{LT}_{50}$ values of $0.0020 \%(\mathrm{w} / \mathrm{v})$ of methanol, ethyl acetate and aqueous fractions of $R$. nasutus for adult were found as 31, 124 and 189 hours and for nymph were 14, 18 and 29 hours respectively in pesticidal assay. Accordingly, methanolic extract was effective in controlling nymph stage of mealybug life cycle than adults with the $\mathrm{LC}_{50}$ of $0.0015 \%(\mathrm{w} / \mathrm{v})$ within 14 hours. This study confirmed promising pediculicidal and pesticidal activity and significant anti-oxidant capacity of leaves of $R$. nasutus.
\end{abstract}

Keywords: Rhinacanthus nasutus; pediculicidal activity; pesticidal activity; DPPH assay; FRAP assay

\section{Introduction}

Plants and plant based products have been used for medicinal and health enhancement purpose since human civilizations and indeed since the evolutionary origin of humans. With the development of science, focus on plant research has increased all over the world and the research on plants that have been used in traditionally for various healthcare purposes have been intensified with the purpose of finding novel bioactive material and potential applications as greener value-added products, pesticides and insecticides (Cordell and Colvard, 2012; Anand et al., 2019; Hamid et al., 2010; Bhattacharya, 2015; Ayoub and Mishra, 2107). Infestation by head lice (Pediculus humanus capitis) is one of the most common parasitic diseases in childhood worldwide, and there is statistics that infestations have increased during the last decade (Falagas, 2008).

The plant, Rhinacanthus nasutus (Acanthaceae), commonly known as "Heen aniththa is an ethnomedical plant which is Aniththa," native to Sri Lanka and widely distributed in North Central and Southern provinces of the country. It is a perennial woody shrub which flowering period is November to December. The history indicated the use of this plant in Sri Lankan traditional system of medicine to treat various ailments including eczema, pulmonary tuberculosis, herpes, hepatitis, diabetes, hypertension, several skin diseases, cancers, curing ringworms related diseases and parasitic skin diseases, healing wounds, reducing dermatitis, (Devanarayana et al., 2015; Bukke et al., 2011). Some bioactive compounds and some pharmacological activities have been discovered from leaves of $R$. nasutus by researchers around the globe (Thongrakard and Tencomnao, 2010; 
Brimson and Tencomnao, 2011; Punturee, 2004; Zubaid, 2009). The main bioactive constituents identified in the leaves were naphthoquinones and rhinacanthones which are known to have anti-proliferative activity against cancer cells (Siripong, 2006).

In Sri Lanka contest, no adequate reports are available on scientific investigation of this multi-functional native plant in Sri Lanka, and so far no studies has been done to explore its pediculicidal and pesticidal activities. Therefore, this study was aimed on investigation of anti-oxidant capacity, pediculicidal and pesticidal activities of leaves of $R$. nasutus grown in Sri Lanka.

\section{Materials and Methods}

\subsection{Chemicals used in the study}

All the chemicals and reagents including methanol, hexane, ethyl acetate, chloroform, L-ascorbic acid, 2,2'diphenyl-1-picrylhydrazyl (DPPH), 2,4,6-tris(2-pyridyl)-s-triazine (TPTZ) used in this study were of analytical grade and purchased from Sigma-Aldrich.

\subsection{Plant material}

Leaves of $R$. nasutus were collected from a domestic cultivation of Puttalam district, Sri Lanka and authenticated. Healthy leaves were washed and dried under breeze at room temperature for one week. The dried leaves were grounded into fine powder using a blender and were stored in sealed containers at $4{ }^{\circ} \mathrm{C}$ until usage.

\subsection{Extraction of plant constituents}

The methanolic extract of leaves was prepared by macerating in methanol for five days with frequent agitation. The macerated solution was filtered and concentrated under vacuum, and suspended in distilled water. The water suspended material was subjected to sequentially extraction with n-hexane, chloroform, ethyl acetate and aqueous as the remain fraction. All the extracts were concentrated under vacuum and stored at $4{ }^{\circ} \mathrm{C}$ until tests were performed (Bulugahapitiya, 2013).

\subsection{Determination of antioxidant capacity}

Anti-oxidant capacity was determined using 2,2-diphenyl-1-picrylhydrazyl radical scavenging assay (DPPH assay) and ferric reducing antioxidant power assay (FRAP assay), and ascorbic acid and $\mathrm{FeSO}_{4} \cdot 7 \mathrm{H}_{2} \mathrm{O}$ were used as the standards respectively (Gohari et al., 2011; Amaeze et al., 2011; Soonwera, 2016).

\subsubsection{2,2-Diphenyl-1-picrylhydrazyl (DPPH) radical scavenging assay}

The concentrations of plant extracts were prepared as $25,50,75,100,200,400,600,800$ and $1000 \mu^{-g m L^{-}}$ Ascorbic acid was used as the standard, and the similar concentrations were prepared with the plant extract. The test solutions were prepared by mixing $1 \mathrm{~mL}$ of the extract and standard with $3 \mathrm{~mL}$ of DPPH solution. The solutions were kept in dark for 30 minutes at room temperature. The absorbance was measured at $517 \mathrm{~nm}$ using the UV-Vis spectrophotometer (UH5300 -HITACHI). The free radical scavenging activity was expressed as $\mathrm{IC}_{50}$ using \% inhibition vs. concentration plot. The \% inhibition was calculated from[(AB-AA)/AB] x100, Where $\mathrm{AB}$ is the absorption of the DPPH without extract and AA is the absorption of the DPPH solution containing plant extract or ascorbic acid.

\subsubsection{Ferric Reducing Antioxidant Power (FRAP) assay}

Freshly prepared FRAP reagent $(3.00 \mathrm{~mL})$ was mixed with $0.4 \mathrm{~mL}$ of extract and absorbance was recorded at $593 \mathrm{~nm}$ after $30 \mathrm{~min}$ incubation at $37^{\circ} \mathrm{C}$. An aqueous solution of $\mathrm{FeSO}_{4} \cdot 7 \mathrm{H}_{2} \mathrm{O}\left(20-150 \mu \mathrm{gmL}^{-1}\right)$ was used as the standard for calibration.

\subsection{Pediculicidal assay}

Adult head lice were collected from infested children 7-15 years old with the approval of their parents. The lice were collected by visual search of the hair and combing the scalp using a fine-toothed anti-louse comb. Viable head lice were obtained and pooled by removing them from the comb into clean glass boxes and kept cool and shaded (Kosalge and Fursule, 2009). Modified filter paper diffusion in-vitro bio assay was used to evaluate pediculicidal activity of plant extracts within an hour after collection (Capinera, 2008). Filter paper discs and strips coinciding with internal surfaces of petri dish were placed and lice were kept on filter papers and exposed to fixed concentration $0.0010 \%(\mathrm{w} / \mathrm{v})$ crude extracts dissolved in water using sonication. Then the petri dishes were covered with the cellophanes with small holes allowing ventilation. Distilled water was used as negative control and commercially available head lice lotion containing $0.5 \%(\mathrm{w} / \mathrm{v})$ permethrin was used as the positive 
control. Lice mortalities were monitored using magnifying lens in specific time intervals at $0.5,1,2,4$ and 8 hours after treatment. The criteria used to evaluate survival of lice were defined as the complete absence of any vital signs. If any signs of life such as leg movements were observed, the lice were considered as alive. The lice were judged as dead if there were no vital signs at all. The mortality was calculated using the following formula (Finney, 1952).

Mortality $=\frac{\text { Total number of dead lice }}{\text { Total sample size }} \times 100$

The time which kill a 50\% of head lice $\left(\mathrm{LT}_{50}\right)$ were determined varying the concentrations (Majeed et al, 2018).

\subsection{Pesticidal assay}

Mealybugs were used to investigate pesticidal activity of the plant. They are common pests of houseplants. These species remove plants sap from above ground plant parts, especially stem tips, leaf junctures and new growth. Their feeding weakens and stunts plants, and causes foliar yellowing, defoliation, wilting and general plant decline. Mealybugs were collected from infested plants of papaw and guava cultivation which is located around University of Ruhuna, Sri Lanka. They were taxonomically identified as P. marginatus with the help of Department of Zoology, University of Ruhuna, Sri Lanka. Then adult mealybug individuals and nymphs were separated in to glass box using a tiny brush (Karamaouna et al., 2012).

Filter paper contact bioassay with slight modifications was conducted to evaluate the pesticidal activity (Maheshu et al., 2010). The setup of the experiment was same as the above pediculicidal assay. Two life stages of mealybugs such as nymphs and adult females were tested in this assay. Distilled water was used as negative control. Pest mortality was recorded in specific time intervals at 2, 4, 6, 12 and 24 hours after application. The mealybugs were judged as dead if there were no body movements at all. The median lethal time $\left(\mathrm{LT}_{50}\right)$ and lethal concentration (LC50) was calculated as above using probit analysis.

\subsection{Statistical analysis}

Mortality data of head lice and mealybugs at all treatments were subjected to probit analysis to determine the $\mathrm{LT}_{50}$ and $\mathrm{LC}_{50}$ values of each solvent extracts of $R$. nasutus. $\mathrm{R}$ statistical software was used for all these statistical analyses.

\section{Results and Discussion}

\subsection{Anti-oxidant activity}

The results of percentage inhibitions of standard ascorbic acid and methanolic extract with respect to different concentrations are given in the Figure 1.

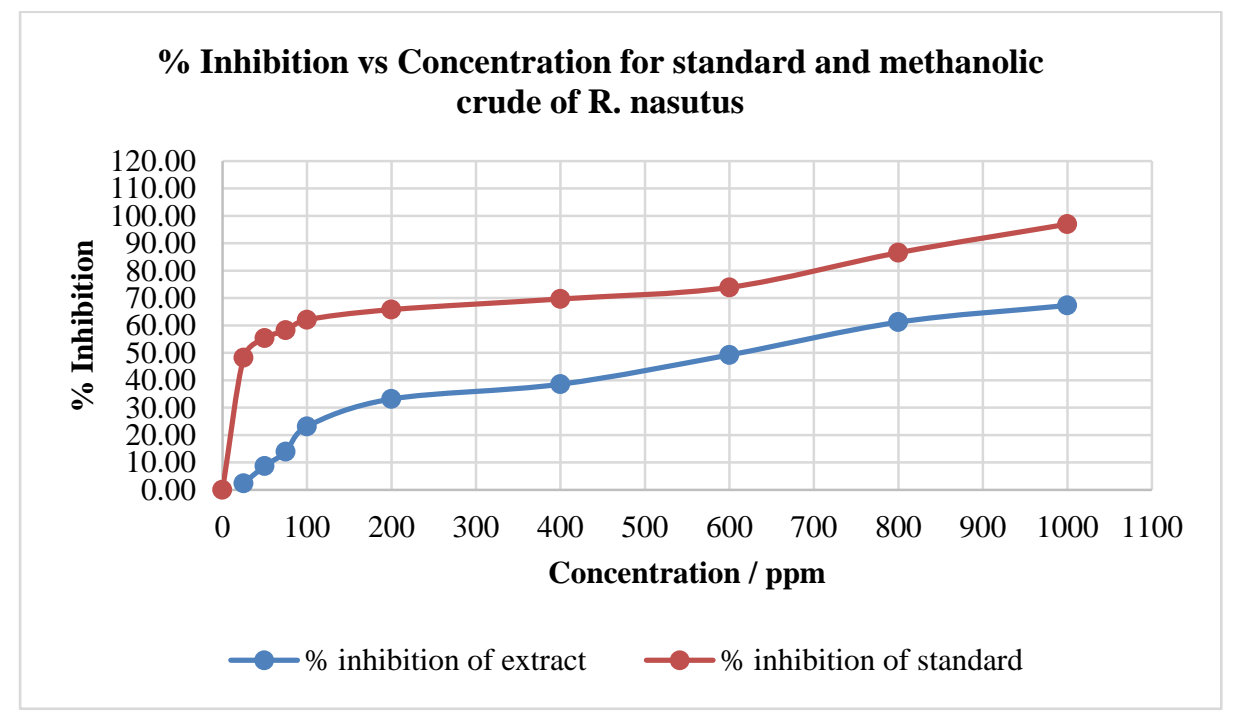

Figure 1. Percentage inhibition vs concentration for the standard series and the methanolic extract of R.nasutus in DPPH assay.

According to the percentage inhibition of DPPH, the calculated $\mathrm{IC}_{50}$ values were $40.7 \mu \mathrm{gmL}^{-1}$ and $514.3 \mu \mathrm{gmL}^{-1}$ for ascorbic acid and methanolic extract of $R$. nasutus respectively. DPPH is a stable free radical which is reduced in the presence of hydrogen donating antioxidants. Polyphenols present in plants are main responsible 
for anti-oxidants activity exerted. Bukke et al. (2013) has reported the $\mathrm{IC}_{50}$ value of $230 \mu \mathrm{gmL}^{1}$ for dry powder of the plant. They have also reported the antioxidant power of hexane, ethyl acetate, methanol and water extracts of $R$. nasutus leaves using DPPH assay, and $\mathrm{IC}_{50}$ values were lower than values obtained in this study (Bagavan et al., 2009).

In FRAP assay, the antioxidant capacity was determined using the reducing power of the plant extract. The mean FRAP equivalent value was found to be $594.33 \pm 2.93 \mu \mathrm{mol} \mathrm{Fe} \mathrm{F}^{2+} / \mathrm{g}$ for crude methanolic extract. The FRAP assay treats the antioxidant in the sample as reductants in redox linked colorimetric reaction and the value reflect the reducing power of the antioxidants. In this assay, the antioxidants react with $\mathrm{Fe}^{3+}$-TPTZ to produce a coloured $\mathrm{Fe}^{2+}$-TPTZ complex which is measured at $593 \mathrm{~nm}$. FRAF value of this study showed the highest FRAP value indicating highest total antioxidant capacity. Notably, there are no available records from Sri Lankan studies to compare the antioxidant capacity of $R$. nasutus grown in Sri Lanka.

\subsection{Pediculicidal activity}

The average percentage mortality of head lice in methanol, ethyl acetate and aqueous extracts of $R$. nasutus is shown in Table 1.

Table 1. Average percentage mortalities of head lice at different crude solvent extracts of $R$. nasutus.

\begin{tabular}{|c|c|c|c|c|c|}
\hline \multirow[b]{2}{*}{ Time /min } & \multicolumn{5}{|c|}{ Average \% mortality } \\
\hline & $\begin{array}{l}\text { Methanolic } \\
\text { crude }\end{array}$ & $\begin{array}{l}\text { Ethyl acetate } \\
\text { crude }\end{array}$ & Aqueous crude & Negative control & Positive control \\
\hline 30 & 0 & 0 & 0 & 0 & 90 \\
\hline 60 & 0 & 0 & 0 & 0 & 100 \\
\hline 120 & 10 & 10 & 0 & 0 & 100 \\
\hline 240 & 50 & 30 & 10 & 0 & 100 \\
\hline 480 & 90 & 60 & 40 & 0 & 100 \\
\hline
\end{tabular}

The $\mathrm{LT}_{50}$ values obtained from probit analysis for mortality values of $0.0010 \%$ (w/v) of methanolic, ethyl acetate and aqueous extract were found to be 263,347 and $676 \mathrm{~min}$. The methanolic fraction were highly active against head lice.

The whole bioassay procedure was repeated for active methanolic extract of $R$. nasutus with varying concentrations as $0.0005 \%, 0.0010 \%, 0.0015 \%, 0.0020 \%$ and $0.0025 \%$ in w/v basis. The $\mathrm{LC}_{50}(50 \%$ mortality) value was found to be $0.0011 \%(\mathrm{w} / \mathrm{v})$ after $240 \mathrm{~min}$ which was calculated using the graph of probit mortality versus $\log$ concentration as indicated in the Figure 2.

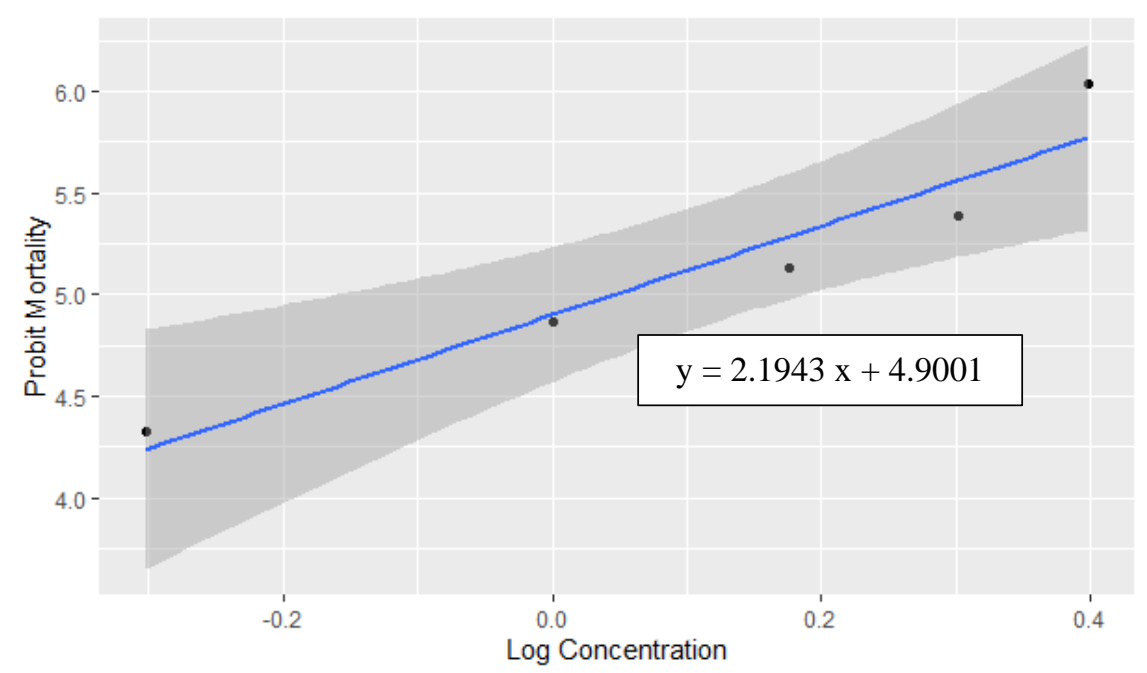

Figure 2. The graph of Probit mortality vs. Log concentration in Pediculicidal Assay.

The data in this bioassay highlights that methanolic extract of R. nasutus is highly toxic to head lice with $90 \%$ mortality at $480 \mathrm{~min}$. Further, the $0.0010 \%(\mathrm{w} / \mathrm{v})$ of methanolic extract has lowest $\mathrm{LT}_{50}$ value. Therefore, methanol extract showed high levels of mortality on adult lice in short time than the other extracts. Based on the above results, it is evident that $R$. nasutus has high potential to kill lice and hence, therefore there is an extensive scope for development into products of pediculicidal activity. It is noteworthy that there is no recorded literature 
available for this plant species in terms of pediculicidal studies and this work is recognized as the first study related to this

\subsection{Pesticidal assay}

The average percentage mortality values for adults and nymph stages of mealybug are given in the Table 2 .

Table 2. Average percentage mortalities of adult mealybugs and nymphs at different crude extracts of $\boldsymbol{R}$. nasutus with respect to different exposure times.

\begin{tabular}{llllllll}
\hline \multirow{2}{*}{$\begin{array}{l}\text { Time } \\
\text { hours }\end{array}$} & \multicolumn{6}{c}{ Average percentage mortality / \% } \\
\cline { 2 - 7 } & $\begin{array}{llllll}\text { Adult mealybugs } \\
\text { Methanolic } \\
\text { crude }\end{array}$ & $\begin{array}{l}\text { Ethyl } \\
\text { crude }\end{array}$ & $\begin{array}{l}\text { acetate } \\
\text { Aqueous } \\
\text { crude }\end{array}$ & $\begin{array}{l}\text { Methanolic } \\
\text { crude }\end{array}$ & $\begin{array}{l}\text { Ethyl } \\
\text { crude }\end{array}$ & $\begin{array}{l}\text { acetybugs } \\
\text { crudeous } \\
\text { crude }\end{array}$ \\
\hline 2 & 0 & 0 & 0 & 0 & 0 & 0 \\
4 & 0 & 0 & 0 & 0 & 0 & 0 \\
6 & 0 & 0 & 0 & 15 & 5 & 0 \\
12 & 10 & 0 & 0 & 60 & 35 & 10 \\
24 & 35 & 20 & 10 & 85 & 60 & 45 \\
\hline
\end{tabular}

Based on the results different extracts of $R$. nasutus it shows that nymphal mortality is significant compare to the adult mealybug mortality. The $\mathrm{LT}_{50}$ values of each $0.0020 \%(\mathrm{w} / \mathrm{v})$ of methanolic, ethyl acetate and aqueous factions were 31, 124 and 189 hours for the adult mortality and 14, 18 and 29 hours for the nymph mortality respectively. Methanolic fraction was highly active against both adult and nymph stage of the mealybug and the $\mathrm{LC}_{50}(50 \%$ mortality) value recorded as $0.0015 \%(\mathrm{w} / \mathrm{v})$ after 14 hours which was calculated by using the graph of probit mortality versus log concentration as indicated in the Figure 3.

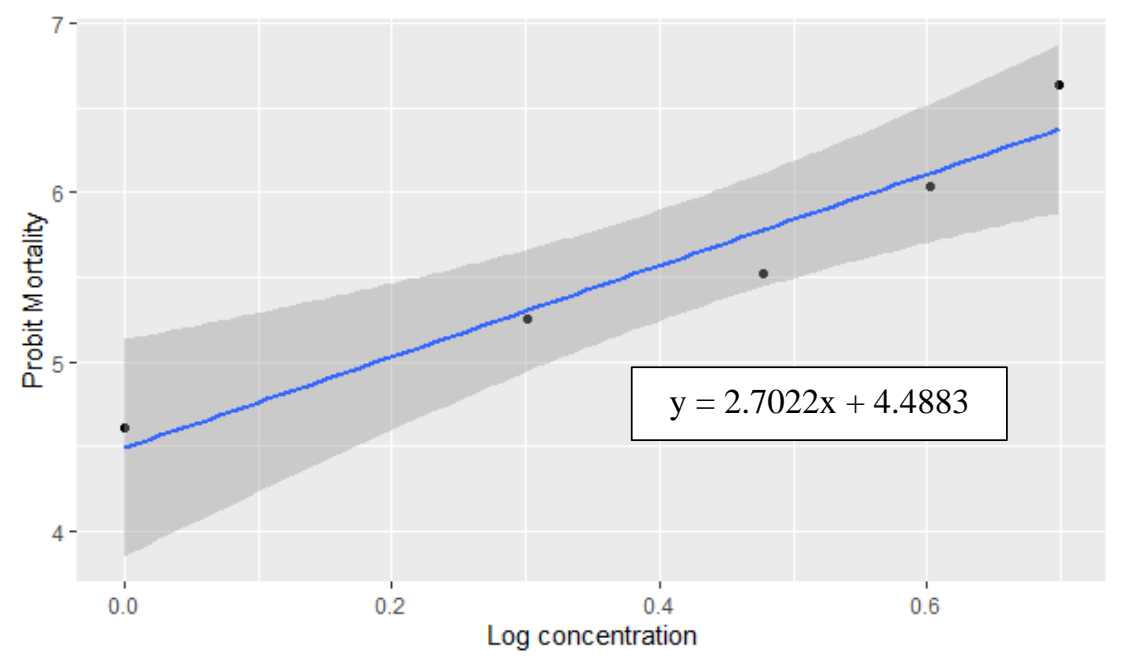

Figure 3. The graph of Probit mortality vs. Log concentration in Pesticidal assay.

The data in this pesticidal assay brought to notice that nymph stage of mealybug life cycle is the most susceptible stage to the plant extracts in term of pesticidal activity, and methanol extract showed $50 \%$ of mortality on nymph stage of mealybugs in 14 hours, with $\mathrm{LC}_{50}$ value of $0.0015 \%$ (w/v). It is noteworthy that there is no recorded literature available for this plant species in terms of pesticidal activity against mealybugs. However, R. nasutus has been studied against few pest insects by other researchers (Fadli et al, 2017; Peschiutta et al, 2018). However, contact pesticides are less effective against mealybugs because of their cryptic habitats in plants and the water proof waxy layer on the body. Therefore, the field trials should be necessary in order to check the reliability of plant extracts in control of mealybugs. Also, these results give an insight into the potential use of the $R$. nasutus as botanical pesticide especially against mealybug species on cultivated fruit crops in Sri Lanka.

\section{Conclusions}

This study confirmed that the leaves of $R$. nasutus exert promising pediculicidal activity and pesticidal activity against mealybugs. The methanolic extract of $R$. nasutus encompasses the highest activity in all performed tests. 
The high antioxidant activity of leaves signifies the multifunctional therapeutic potential of $R$. nasutus. Further clinical trials and field trials will be needed to assess the accuracy of the laboratory results of in-vitro pediculicidal and pesticidal assays in order to develop it into value added products.

\section{Conflict of interest}

None to declare.

\section{References}

Amaeze OU, GA Ayoola, MO Sofidiya, AO Adegoke and HAB Coker, 2011. Evaluation of antioxidant activity of Tetracarpidium conophorum (Mull.Arg) Hutch \& Dalziel leaves. Oxid. Med. Cell Longev., 2011: 976701.

Anand U, HN Jacobo, A Altemimi and U Lakhssassi, 2019. A comprehensive review on medicinal plants as antimicrobial therapeutics: potential avenues of biocompatible drug discovery. Metabolites, 9: 258 .

Ayoub Z and S Mishra, 2017. Medicinal plants as natural antioxidants: a review. J. Bot. Soc., 48.

Bagavan A, C Kamaraj, RA Abdul, G Elango, ZA Abduz and G Pandiyan, 2009. Evaluation of larvicidal and nymphicidal potential of plant extracts against Anopheles subpictus Grassi, Culex tritaeniorhynchus Giles and Aphis gossypii Glover. Parasitol. Res., 104: 1109-1117.

Bhattacharya S, 2015. Reactive oxygen species and cellular defense mechanism. Free Radicals in Human Health and Disease, pp. 17-29.

Brimson JM and T Tencomnao, 2011. Rhinacanthus nasutus protects cultured neuronal cells against hypoxia induced cell death. Molecules, 16: 6322-6338.

Bukke S, K Thyagaraju and M Venkataswamy, 2013. Phytochemical analysis, in-vitro antioxidant activity and proximate analysis on Rhinacanthus Nasutus (L) Kurz leaf. Indian Journal of Applied Research, 3: 32-35.

Bukke S, PS Raghu, G Sailaja and TR Kedam, 2011. The study on morphological, phytochemical and pharmacological aspects of Rhinacanthus nasutus. (L) kurz (A review). J. Appl. Pharm. Sci., 1: 26-32.

Bulugahapitiya VP, 2013. Plants Based Natural Products Extraction, Isolation and Phytochemical Screening. 1st edition, Sri Lanka.

Capinera JL, 2008. Encyclopedia of Entomology. 2nd ed. vol 4: Springer Science.

Cordell GA and MD Colvard, 2012. Importance of ethnopharmacological studies in drug discovery: role of medicinal plants. Indian J. Nat. Prod. Resour., 75: 514-525.

Devanarayana A, ERHSS Ediriweera, SSBDP Soysa and N Karunarathna, 2015. Therapeutic usages of Rhinacanthus Nasutus (L) Kurz (Aniththa) in Sri Lankan traditional medicine unique. J. Ayurvedic Herb Med., 3: 10-15.

Fadli A, D Soelistya, D Jekti and S Bahri, 2017. Toxicity test of methanol extract of Rhinacanthus nasutus L.Kurz. leaf to Spodoptera litura F. IOSR Journal of Environmental Science, Toxicology and Food Technology, 11: 60-63.

Falagas ME, DK Matthaiou, PI Rafailidis, G Panos and G Pappas, 2008. Worldwide prevalence of head lice. Emerg. Infect. Dis., 14: 1493.

Finney DJ, 1952. Probit Analysis. 2 nd ed. New York: Cambridge University Press.

Gohari AR, H Hajimehdipoor, S Saeidnia and Y Ajani, 2011. Antioxidant activity of some medicinal species using FRAP assay. Journal of Medicinal Plants, 10: 54-60.

Hamid AA, OO Aiyelaagbe, LA Usman, OM Ameen and A Lawal, 2010. Antioxidants: its medicinal and pharmacological applications. Afr. J. pure Appl. Chem., 4: 142-151.

Karamaouna F, A Kimbaris, M Polissiou and P Papatsakona, 2012. Insecticidal activity of plant essential oils against the vine mealybug, Planococcus ficus. Journal of Insect Science, 131: 1-13.

Kosalge SB and RA Fursule, 2009. Investigation of licicidal activity of some plants from Satpuda hills. Int. J. Pharm.Tech. Res., 1: 564- 567.

Maheshu V, JM Sasikumar and DTP Darsini, 2010. In Vitro Antioxidant Activity and Polyphenolic Contents of Rauvolfia tetraphylla L., Rhinacanthus nasutus Kurz. and Solena amplexicaulis (Lam.). Int. J. Biomed. Pharma. Sci., 4: 81-86.

Majeed MZ, MI Nawaz and RR Khan, 2018. Insecticidal effect of some plant extracts on citrus mealybug Planococcus citri (Risso) (Hemiptera : Pseudococcidae). Tropical and Subtropical Agroecosystems, 21: 421430.

Peschiutta M, V Brito, F Achimón, J Dambolena and JA Zygadlo, 2018. Laboratory evaluation of insecticidal activity of plant essential oils against the vine mealybug, Planococcus ficus. Vitis, 56: 79-83.

Punturee K, CP Wild and U Vinitketkumneun, 2004. Thai medicinal plants modulate nitric oxide and tumor necrosis factor in J774.2 mouse macrophages. J. Ethnopharmacol., 95: 183-189. 
Siripong P, J Yahuafai and K Shimizu, 2006. Antitumor activity of liposomal naphthoquinone esters isolated from Thai medicinal plant: Rhinacanthus nasutus Kurz. Biol. Pharm. Bull., 29: 2279-2283.

Soonwera M, 2016. Chemical composition and efficacy of some selected plant oils against Pediculus humanus capitis in vitro. Int J Agri Tech., 12: 657-666.

Thongrakard V and $\mathrm{T}$ Tencomnao, 2010. Modulatory effects of Thai medicinal plant extract on proinflammatory cytokines-induced apoptosis in human keratinocyte HaCaT cells. Afr. J. Biotechnol., 9: 4999-5003.

Thongrakard V and $\mathrm{T}$ Tencomnao, 2010. Modulatory effects of Thai medicinal plant extract on proinflammatory cytokines-induced apoptosis in human keratinocyte HaCaT cells. Afr. J. Biotechnol., 9: 4999-5003.

Zubaid M, NA Abdullah and AM Noor, 2009. Evaluation of anti-fungal and anti-bacterial activity of a local plant Rhinacanthus nasutus (L.). J. Biol. Sci., 4: 498-500. 